\title{
Application of Preplant Fumigants via Drip Irrigation Systems for the Management of Root Rot of Melons Caused by Monosporascus cannonballus
}

\author{
M. E. Stanghellini, D. M. Ferrin, D. H. Kim, M. M. Waugh, K. C. Radewald, J. J. Sims, and H. D. Ohr, \\ Department of Plant Pathology, University of California, Riverside 92521; K. S. Mayberry and T. Turini, UCCE, \\ Holtville, CA 92250; and M. A. McCaslin, TRI-CAL, Inc., Corona, CA 92882
}

\begin{abstract}
Stanghellini, M. E., Ferrin, D. M., Kim, D. H., Waugh, M. M., Radewald, K. C., Sims, J. J., Ohr, H. D., Mayberry, K. S., Turini, T., and McCaslin, M. A. 2003. Application of preplant fumigants via drip irrigation systems for the management of root rot of melons caused by Monosporascus cannonballus. Plant Dis. 87:1176-1178.

Root rot and vine decline, caused by Monosporascus cannonballus, is a destructive disease of melons in the desert production regions of southern California. In 1998, we initiated studies on the use of preplant fumigation to reduce resident pathogen populations in soil. Preplant fumigation with methyl iodide injected as a hot gas at $448.4 \mathrm{~kg} / \mathrm{ha}$ through drip irrigation tape in preformed, tarped beds consistently provided significant $(P<0.05)$ reductions in the percentage of roots infected compared with the nonfumigated controls; these reductions were equal to or better than those achieved with an equivalent rate $(448.4 \mathrm{~kg} / \mathrm{ha})$ of methyl bromide. Chloropicrin applied in water at $249.0 \mathrm{~kg} / \mathrm{ha}$ through buried drip irrigation tape to either tarped or nontarped beds significantly $(P<0.05)$ reduced the percentages of both roots infected and roots on which perithecia were produced compared with nonfumigated controls.
\end{abstract}

Root rot and vine decline of melons (Cucumis melo L.) caused by Monosporascus cannonballus Pollack \& Uecker (11), a root-infecting ascomycete, is a destructive disease in arid and semi-arid regions of the world $(2,10)$. This disease constitutes a serious threat to continued cultivation of melons in the desert production regions of southern California (5). No commercially acceptable resistant cultivars are available and no fungicides currently are registered for the control of this pathogen on melons in the United States. Preplant fumigation of pathogen-infested fields with methyl bromide has proven efficacious for disease control (2). However, the production of methyl bromide is to be banned in the United States by the year 2005 and worldwide by 2015. Thus, alternative disease management strategies are needed.

Our investigations on the biology of $M$. cannonballus demonstrated that (i) the pathogen is an indigenous soilborne fungus (14), (ii) ascospores function as the primary survival structure and as inoculum for root infection in field soil $(14,15)$, (iii) pathogen reproduction (i.e., perithecia and ascospore production) occurs primarily at the end of the growing season (18), and (iv) ascospore populations of approxi-

Corresponding author: M. E. Stanghellini

E-mail: mstang@ucrac1.ucr.edu

Accepted for publication 2 May 2003.

Publication no. D-2003-0714-02R

(C) 2003 The American Phytopathological Society mately 2 or more per gram of soil are associated with significant crop losses (M. E. Stanghellini, unpublished data). The cumulative results of these studies led to the development of a disease management strategy that consists of (i) reducing the amount of primary inoculum in soil with a preplant soil fumigant, and then (ii) maintaining low population levels by inhibiting pathogen reproduction in infected melon roots left in the field after crop termination.

The efficacy of two methyl bromide-alternative preplant soil fumigants, methyl iodide and chloropicrin, in reducing the incidence of roots with lesions caused by or perithecia produced by $M$. cannonballus is presented herein. A preliminary report has been published (16).

\section{MATERIALS AND METHODS}

The efficacy of preplant soil applications of methyl iodide and chloropicrin for the control of root rot of melons caused by $M$. cannonballus was determined in four field experiments conducted at the University of California Desert Research and Extension Center (DREC) in Holtville, CA. The resident population density of $M$. cannonballus in the naturally infested plot site at DREC was estimated (17) at 2.8 ascospores/g of soil (Meloland sandy loam).

All soil fumigant treatments were applied prior to planting of the spring crops. With the exception of the experiment in 2001, all experiments were established using a randomized complete block design with four blocks. In 2001, a randomized complete block design with three blocks was used; subplots consisting of tarped and nontarped subtreatments were included in each of the treatment plots. Each treatment was applied to a single bed $33 \mathrm{~m}$ in length and $137 \mathrm{~cm}$ wide. Beds were on 203-cm centers. Each bed was prepared by installing a drip irrigation line (T-tape with 20.3-cm spacing between emitters delivering $0.025 \mathrm{liters} / \mathrm{min}$ at $8 \mathrm{psi}$ ) at the $20-\mathrm{cm}$ soil depth. Prior to fumigation, beds were covered with 1.25-mil high barrier black polyethylene tarp that covered the entire width of the bed, and the edges of the tarps were buried to seal them. A susceptible melon cultivar (Caravelle) was seeded into the center of each bed with $30.5-\mathrm{cm}$ spacing between plants. Standard local cultural practices were employed for insect control, fertilization, irrigation frequency, and weed management.

The fumigants tested were methyl bromide (Great Lakes Chemical, West Lafayetee, IN), methyl iodide (iodomethane; D.S.M. Fine Chemicals, Saddle Brook, $\mathrm{NJ}$ ), and chloropicrin (trichloronitromethane; Tri-Clor EC, TriCal, Inc., Hollister, CA).

In the first experiment, conducted in spring 1998, methyl bromide at 448.4 $\mathrm{kg} / \mathrm{ha}$ and methyl iodide at 112.1 and 448.4 $\mathrm{kg} / \mathrm{ha}$ were applied to tarped beds using a hot gas fumigation applicator as previously described (7). Treatments were applied on 11 March, plots were seeded on 18 March, and data were collected on 10 July. These treatments were repeated in the second experiment, conducted in spring 1999, with the addition of chloropicrin at 166.2, 249.0 , and $332.1 \mathrm{~kg} / \mathrm{ha}$. The chloropicrin was injected into tarped beds via the drip irrigation system with an injection time of $7 \mathrm{~h}$ followed by a 20-min clean-water flush. Treatments were applied on 11 March, plots were seeded on 18 March, and data were collected on 30 June. In the third experiment, conducted in spring 2001, only chloropicrin was tested and was applied at $249.0 \mathrm{~kg} / \mathrm{ha}$ to tarped and nontarped beds via the drip system as described above. Treatments were applied on 17 May, plots were seeded on 5 June, and data were collected on 14 August. In the fourth experiment, conducted in spring 2002, chloropicrin was applied at 249.0 $\mathrm{kg} / \mathrm{ha}$ to nontarped beds via the drip systems as described above. Treatments were applied on 26 February, plots were seeded on 18 March, and data were collected on 9 July. 
At the end of each cropping season, the root systems of 15 to 20 plants from each replication of each treatment were carefully excavated from soil, gently washed, and visually evaluated for the following: number of roots per plant, number of roots bearing lesions typical of those incited by M. cannonballus, and number of roots bearing perithecia of $M$. cannonballus. After visual evaluation, five lesions per treatment were excised from symptomatic roots and plated on water agar. Hyphae emerging from lesions were transferred to $10 \% \mathrm{~V} 8$ agar medium for identification. $M$. cannonballus was recovered successfully from 90 to $100 \%$ of these lesions. Data were converted to proportions of roots with lesions and proportion of roots with perithecia. Analysis of variance was calculated using the general linear models procedure (GLM) of SAS (SAS Institute, Cary, NC) following arcsine transformation of the data. Means were separated using Fisher's protected least significant difference (LSD) test or Student's $t$ test.

\section{RESULTS AND DISCUSSION}

The data from experiments conducted over 4 years are summarized in Table 1 . Preplant fumigation with methyl iodide injected as a hot gas at $448.4 \mathrm{~kg} / \mathrm{ha}$ through drip irrigation tape in preformed, tarped beds consistently provided significant $(P<$ 0.05 ) reductions in the percentage of roots infected compared with the nonfumigated controls; these reductions were equal to or better than those achieved with an equivalent rate $(448.4 \mathrm{~m} \mathrm{~kg} / \mathrm{ha})$ of methyl bromide. Chloropicrin applied in water at $249.0 \mathrm{~kg} / \mathrm{ha}$ through buried drip irrigation tape to either tarped or nontarped beds significantly $(P<0.05)$ reduced the percentages of both roots infected and roots on which perithecia were produced compared with nonfumigated controls.

Methyl iodide is effective against many fungi (8), nematodes (6,7), and weeds (20) and its activity closely parallels that of methyl bromide (4); therefore, it has been suggested as a direct replacement for methyl bromide. We found it to be quite effective in the control of root rot caused by $M$. cannonballus. Furthermore, preliminary results suggested that methyl iodide was more efficacious when applied in water through drip irrigation tape than when "flashed" on as a hot gas (M. E. Stanghellini, unpublished data).

As a soil fumigant, chloropicrin is effective against fungi $(8,9)$ and nematodes (9), but has little effect on weeds (4). Traditionally, it has been used in combination with methyl bromide and, in the search for replacements for methyl bromide, it also generally has been used in combination with other fumigants $(3,13,19)$. This is the first report to demonstrate that chloropicrin alone is effective in reducing root infections caused by $M$. cannonballus. In fact, our data suggested that chloropicrin alone was as effective as methyl bromide or methyl iodide in reducing the incidence of root infection of melons when it was applied in water through the irrigation drip tape in preformed beds.

The application of water-soluble formulations of soil fumigants through buried drip irrigation tape in preformed beds allows for the efficient placement of the materials in the soil that will become the root zone of the subsequent crop. This is a much more economical and environmen- tally friendly method of application than broad-scale shank injection (1) and has been used successfully to control a variety of pathogens $(7,13,16,19)$. However, because fumigation does not completely eliminate the pathogen, additional postharvest management practices are necessary to destroy infected roots left in the field after harvest and prevent pathogen reproduction. This is a vital part of the integrated management program for the control of $M$. cannonballus that we have proposed. Studies on postharvest strategies to prevent pathogen reproduction in infected roots are currently in progress (12).

\section{LITERATURE CITED}

1. Ajwa, H. A. 2000. Application of alternative fumigants through drip irrigation systems. (Abstr.) Phytopathology 90:S102.

2. Cohen, R., Pivonia, S., Berger, Y., Edelstein, M., Gamliel, A., and Katan, J. 2000. Toward integrated management of Monosporascus wilt of melons in Israel. Plant Dis. 84:496505.

3. Csinos, A. S., Johnson, W. C., Johnson, A. W., Sumner, D. R., McPherson, R. M., and Gitaitis, R. D. 1997. Alternative fumigants for methyl bromide in tobacco and pepper transplant production. Crop Prot. 16:585-594.

4. Duniway, J. M. 2000. Status of chemical alternatives to methyl bromide for pre-plant fumigation of soil. (Abstr.) Phytopathology 90:S102.

5. Holmes, G. J, and Stanghellini, M. E. 1998. Monosporascus root rot of melons in Imperial Valley, California. (Abstr.) Phytopathology 88:S121.

6. Hutchinson, C. M., McGiffen, M. E., Ohr, H. D., Sims, J. J., and Becker, J. O. 1999. Efficacy of methyl iodide soil fumigation for the control of Meloidogyne incognita, Tylenchulus semipenetrans, and Heterodera schachtii. Nematology 1:407-414.

7. Hutchinson, C. M., McGiffen, M. E., Jr., Ohr, H. D., Sims, J. J., and Becker, J. O. 1999.

Table 1. Effect of fumigants applied via drip irrigation systems on the incidence of lesions and perithecia of Monosporascus cannonballus on melon roots $^{\mathrm{w}}$

\begin{tabular}{|c|c|c|c|c|c|}
\hline Treatment $^{\mathrm{x}}$ & Rate (kg/ha) & Application methody & Tarp/no tarp & Roots with lesions $(\%)^{\mathrm{z}}$ & Roots with perithecia $(\%)$ \\
\hline \multicolumn{6}{|l|}{ Experiment 1} \\
\hline Check & NA & Water & Tarp & $63.8 \mathrm{a}$ & $\ldots$ \\
\hline Methyl bromide & 448.4 & Hot gas & Tarp & $49.4 \mathrm{a}$ & $\ldots$ \\
\hline Methyl iodide & 112.1 & Hot gas & Tarp & $57.5 \mathrm{a}$ & $\ldots$ \\
\hline Methyl iodide & 448.4 & Hot gas & Tarp & $26.9 \mathrm{~b}$ & $\ldots$ \\
\hline \multicolumn{6}{|l|}{ Experiment 2} \\
\hline Check & NA & Water & Tarp & $66.7 \mathrm{a}$ & $53.3 \mathrm{a}$ \\
\hline Methyl bromide & 448.4 & Hot gas & Tarp & $11.7 \mathrm{bc}$ & $13.3 \mathrm{~b}$ \\
\hline Methyl iodide & 112.1 & Hot gas & Tarp & $65.0 \mathrm{a}$ & $73.3 \mathrm{a}$ \\
\hline Methyl iodide & 448.4 & Hot gas & Tarp & $0.0 \mathrm{c}$ & $0.0 \mathrm{~b}$ \\
\hline Chloropicrin & 166.2 & Water & Tarp & $15.0 \mathrm{bc}$ & $0.0 \mathrm{~b}$ \\
\hline Chloropicrin & 249.0 & Water & Tarp & $18.3 \mathrm{bc}$ & $0.0 \mathrm{~b}$ \\
\hline Chloropicrin & 332.1 & Water & Tarp & $25.0 \mathrm{~b}$ & $0.0 \mathrm{~b}$ \\
\hline \multicolumn{6}{|l|}{ Experiment 3} \\
\hline Check & NA & Water & Tarp & $98.7 \mathrm{a}$ & $26.2 \mathrm{a}$ \\
\hline Check & NA & Water & No tarp & $97.0 \mathrm{a}$ & $14.6 \mathrm{~b}$ \\
\hline Chloropicrin & 249.0 & Water & Tarp & $42.1 \mathrm{~b}$ & $4.0 \mathrm{c}$ \\
\hline Chloropicrin & 249.0 & Water & No tarp & $21.9 \mathrm{c}$ & $2.7 \mathrm{c}$ \\
\hline \multicolumn{6}{|l|}{ Experiment 4} \\
\hline Check & NA & Water & No tarp & $91.5 \mathrm{a}$ & $13.0 \mathrm{a}$ \\
\hline Chloropicrin & 249.0 & Water & No tarp & $25.4 \mathrm{~b}$ & $1.5 \mathrm{~b}$ \\
\hline
\end{tabular}

${ }^{w}$ Within each experiment, data within a column followed by the same letter are not significantly $(P<0.05)$ different from each other according to Fisher's protected LSD test (Experiments 1, 2, and 3) or Student's $t$ test (Experiment 4); NA = not applicable and ... = not determined.

x Treatments for Experiments 1, 2, 3, and 4 were applied on 11 March 1998, 11 March 1999, 17 May 2001, and 26 February 2002, respectively.

y Materials applied in hot gas were applied over a 15-min period. Chloropicrin was applied in water over a 7-h period.

${ }^{\mathrm{z}}$ M. cannonballus was successfully recovered from 90 to $100 \%$ of typical lesions on symptomatic roots that were chosen for isolation. 
Evaluation of methyl iodide as a soil fumigant for root-knot nematode control in carrot production. Plant Dis. 83:33-36.

8. Hutchinson, C. M., McGiffen, M. E., Ohr, H. D., Sims, J. J., and Becker, J. O. 2000. Efficacy of methyl iodide and synergy with chloropicrin for control of fungi. Pest Manage. Sci. 56:413-418.

9. Locascio, S. J., Gilreath, J. P., Dickson, D. W., Kucharek, T. A., Jones, J. P., and Noling, N. W. 1997. Fumigant alternatives to methyl bromide for polyethylene-mulched tomato. Hortscience 32:1208-1211.

10. Martyn, R. D., and Miller, M. E. 1996. Monosporascus root rot and vine decline, an emerging disease of melons worldwide. Plant Dis. 80:716-725.

11. Pollack, F. G., and Uecker, F. A. 1974. Monosporascus cannonballus an unusual Ascomycete in cantaloupe roots. Mycologia 66:346349.

12. Radewald, K. C., Stanghellini, M. E., Kim, D.
H., Waugh, M. M., Mayberry, K. S., and Turini, T. 2001. Vine-decline of melons caused by Monosporascus cannonballus: III. Postharvest disease management strategies. (Abstr.) Phytopathology 91:S74.

13. Seebold, K. W., Csinos, A. S., and Davis, R. F. 2002. Evaluation of in-line injected materials as alternatives to fumigation with methyl bromide. Phytopathology 92:S152.

14. Stanghellini, M. E., Kim, D. H., and Rasmussen, S. L. 1996. Ascospores of Monosporascus cannonballus: germination and distribution in cultivated desert soils in Arizona. Phytopathology 86:509-514.

15. Stanghellini, M. E., Kim, D. H., and Waugh, M. M. 2000. Microbe-mediated germination of ascospores of Monosporascus cannonballus. Phytopathology 90:243-247.

16. Stanghellini, M. E., Kim, D. H., Waugh, M M., Radewald, K. C., Sims, J. J., Ohr, H. D. Mayberry, K. S., Turini, T., and McCaslin, M. A. 2001. Vine-decline of melons caused by
Monosporascus cannonballus: I. Preplant disease management strategies. (Abstr.) Phytopathology 91:S84.

17. Stanghellini, M. E., and Rasmussen, S. L. 1992. A quantitative method for the recovery of ascospores of Monosporascus cannonballus from field soil. (Abstr.) Phytopathology $82: 1115$.

18. Waugh, M. M., Kim, D. H., Ferrin, D. M., and Stanghellini, M. E. 2003. Reproductive potential of Monosporascus cannonballus. Plant Dis. 87:45-50.

19. Webster, T. M., Csinos, A. S., Johnson, A. W., Dowler, C. C., Sumner, D. R., and Fery, R. L. 2001. Methyl bromide alternatives in a bell pepper-squash rotation. Crop Prot. 20:605614.

20. Zhang, W. M., McGiffen, M. E., Becker, J. O. Ohr, H. D., Sims, J. J., and Kallenbach, R. L. 1997. Dose response of weeds to methyl iodide and methyl bromide. Weed Res. 37:181 189. 